\title{
INITIAL GROWTH OF PHLEUM PRATENSE UNDER THE INFLUENCE OF LEAF WATER EXTRACTS FROM SELECTED GRASS SPECIES AND THE SAME EXTRACTS IMPROVED WITH $\mathrm{MgSO}_{4} \cdot 7 \mathrm{H}_{2} \mathrm{O}$
}

\author{
Halina Lipińska ${ }^{1}$, Wojciech Lipiński ${ }^{2}$ \\ ${ }^{1}$ Department of Grassland and Green Forming \\ Agricultural University in Lublin \\ ${ }^{2}$ National Chemical and Agricultural Station, Warsaw
}

\begin{abstract}
In multi-species grassland communities, plant growth and development are modified by both a number of habitat-related factors and physico-chemical processes resulting from the neighbourhood of other species. Plant interactions mediated through chemical substances are identified within the allelopathic processes. The allelopathic process involves excretion of bioactive compounds from plant or microorganisms that inhibit or stimulate physiological processes of the neighbour plants. The allelopathic compounds can exert a harmful impact on the emergence of seedlings, initial development and installation. Therefore, it is essential to reduce the allelopathic influence of the old sward on the plants sown as well to limit the interaction between these new plants. It is claimed that, among others, fertilizer components may partially reduce effects of allelopathic influences

In this study we show the differences in growth inhibition of $\mathrm{Ph}$. pratense seedlings caused by the water extracts of leaves of selected grass species and the amelioration of growth inhibition by addition of magnesium sulfate. The bioassays were performed on Petri dishes under the laboratory conditions. The activity of allelopathic substances in the leaf extracts was evaluated by the degree of inhibition of seed germination, seedling height and root length compared to the control objects (supplied with distilled water). The amelioration of the negative allelopathic effects by a complete nutrient component with or without the addition of magnesium sulfate was also evaluated against the appropriate controls and compared to the objects where blotting-paper was moistened only with leaf extracts.
\end{abstract}

dr hab. Wojciech Lipiński, prof. nadzw., Krajowa Stacja Chemiczno-Rolnicza, ul. Żółkiewskiego 17, 05-075 Warszawa, National Chemical and Agricultural Station, 17 Żółkiewskiego, 05-075 Warsaw, e-mail: wlipinski@schr.gov.pl 
The present studies confirmed the defensive activity of magnesium sulfate against the allelopathic compounds of the tested grass species affecting the initial growth and development of Phleum pratense. The obtained results indicate potential elimination of the allelopathic negative influence of plants through suitable fertilization.

Key words: allelopathy, grasses, magnesium sulphfate, Phleum pratense.

\title{
POCZATKOWY WZROST I ROZWÓJ PHLEUM PRATENSE W WARUNKACH ODDZIAEYWANIA WYCIĄGÓW WODNYCH Z LIŚCI WYBRANYCH GATUNKóW TRAW ORAZ TYCH SAMYCH WYCIĄGÓW WZBOGACONYCH $\mathrm{MgSO}_{4} \cdot 7 \mathrm{H}_{2} \mathrm{O}$
}

\begin{abstract}
Abstrakt
W wielogatunkowych zbiorowiskach roślinnych użytków zielonych wzrost i rozwój roślin jest modyfikowany zarówno przez wiele czynników siedliskowych, jak i procesy fizyczne i chemiczne wynikłe $\mathrm{z}$ sąsiedztwa innych gatunków. Wzajemne oddziaływania roślin za pośrednictwem substancji chemicznych sa utożsamiane z allelopatią. Polega ona na wydzielaniu przez rośliny (lub mikroorganizmy) aktywnych biologicznie substancji chemicznych, które hamują lub stymulują procesy życiowe roślin sąsiadujących. Substancje allelopatyczne moga ujemnie wpływać na wschody, początkowy rozwój i instalację siewek (EMETERIO i in. 2003). Ważne jest zatem ograniczenie allelopatycznych wpływów starej darni na wsiewane rośliny, a także wzajemnych oddziaływań roślin wsiewanych. Uważa się, że m.in. składniki nawozowe moga częściowo niwelować efekty zahamowania na skutek oddziaływań allelopatycznych.

W badaniach podjęto próbę wykazania różnic w zahamowaniu wzrostu siewek Ph. pratense $\mathrm{w}$ warunkach oddziaływania wyciagów wodnych z liści badanych gatunków traw oraz tych samych wyciąów wzbogaconych o wybrane składniki pożywki. Biotesty wykonano na płytkach Petriego w warunkach laboratoryjnych. Za kryterium obecności oraz aktywności substancji allelopatycznych występujących w wyciagach $\mathrm{z}$ liści przyjęto stopień hamowania kiełkowania nasion, wysokości siewek i długości korzeni w stosunku do obiektów kontrolnych (woda destylowana). Efekty niwelowania ujemnych skutków allelopatii przez składniki pożywki oceniano na tle odpowiedniej kontroli $\mathrm{w}$ porównaniu $\mathrm{z}$ obiektami, gdzie bibułę zwilżano tylko wyciągami z liści. W badaniach potwierdzono ochronne oddziaływanie $\mathrm{MgSO}_{4} \cdot 7 \mathrm{H}_{2} \mathrm{O}$ przed allelozwiązkami testowanych gatunków traw oddziałujących na początkowy wzrost i rozwój Phleum pratense. Wykazano możliwość eliminowania ujemnych skutków oddziaływania allelopatycznego roślin poprzez zastosowanie odpowiedniego nawożenia.
\end{abstract}

Słowa kluczowe: allelopatia, trawy, siarczan magnezu, Phleum pratense.

\section{INTRODUCTION}

Withdrawal of some plant species from the grass ecosystems and invasion of others usually accounts for the changes in the soil environment. A progressive decline of the valuable grass species recorded in the grass ecosystems induces their infestation growth, productivity drop and deterioration of feeds obtained. Therefore, it is imperative to restore them. One of the methods recommended to improve the sward species composition 
proves to be undersow, which is conditioned by numerous factors of an economic and natural character. It is assumed that a problem of ineffective undersow is also connected with allelopathy. Although seeds of some grass species are provided with sufficient moisture and light, their emergence may not proceed or be delayed owing to the negative allelopathic impact of the old sward or interactions between the emerging plants. As a consequence, a limited share of the species sown in the sward or even elimination of some species more susceptible to the allelopathic influence has been recorded (EMETERIO et al. 2003, Leigh et al. 1995).

In multispecies plant associations present in a typical grassland, various species constitute a source of allelopathic substances. Their presence has been confirmed in all plant organs. They may be identified in the top (generative and vegetative) and underground ends of plants, in both dead and living parts either on the soil surface or inside it (BERTin et al. 2003, SMith, MARTIN 1994).

Most allelopathic substances, demonstrating a broad spectrum of activity, are detected in leaves. A number of them are water soluble so they can be eluted by rain, fog or dew drops. The presence of allelopathic compounds in the leaves of numerous grass species has been detected in many investigations (Lipińska 2005, Lipińska, Harkot 2005, Smith, Martin 1994, Chung, Miller 1995, Rice 1984, Sutherland et al. 1999).

Allelopathic compounds can exert a harmful impact on the emergence of seedlings, initial development and installation (EMETERIO et al. 2003). Therefore, it is essential to reduce the allelopathic influence of the old sward on the plants sown as well to limit the interaction between these new plants. It is claimed that, among others, fertilizer components may partially reduce effects of allelopathic influences (BLUM et al. 1985). One of the bioelements importantly affecting physiological as well as matter building functions is magnesium. Its deficiency in grasses especially at the beginning of their vegetation, may cause hypomagnesaemia, which is dangerous for the livestock. Increased magnesium doses do not cause over- fertilization, unlike other components (eg. $\mathrm{N}$ or $\mathrm{K}$ ), which deteriorate fodder quality (FILIPEK 1996).

The objective of the present investigations was to evaluate the influence of magnesium as its sulfate salt (a compound used for grassland fertilization) applied to lessen the allelopathic effects of water extracts from leaves of selected grass species on the germination, initial growth and development of Phleum pratense seeds. 


\section{EXPERIMENTAL PROCEDURES}

The investigations were conducted under controlled laboratory conditions on Petri dishes (to avoid the chemical and microbiological interactions which occur in soil). The bioassays were performed under artificial light under a photoperiod of $12 \mathrm{~h}$ (7.00-19.00) provided by high-pressure lamps SON-T Agro (the average light density at the table level circa 3000 lux). Its unique setting (framing/fixture) of SGR 140 type ensured the homogenous light density used for growing plants. The room temperature ranged from 22 to $25^{\circ} \mathrm{C}$.

The studies covered four series of experiments set up according to a fully randomized method in four replications. The initial growth and development of Ph. pratense was compared as following:

\begin{tabular}{|c|c|c|c|}
\hline $\begin{array}{l}\text { Combi- } \\
\text { nation }\end{array}$ & Control Object & Object studied & $\begin{array}{c}\text { Denotation } \\
\text { of } \\
\text { treatment }\end{array}$ \\
\hline 1 & $\mathrm{H}_{2} \mathrm{O}$ & leaf water extracts & $\mathrm{BP}$ \\
\hline 2 & $\mathrm{H}_{2} \mathrm{O}+$ Hoagland 2 & leaf water extracts + Hoagland 2 & $\mathrm{PP}$ \\
\hline 3 & $\begin{array}{l}\mathrm{H}_{2} \mathrm{O}+\text { Hoagland } 2+ \\
+\mathrm{MgSO}_{4} \cdot 7 \mathrm{H}_{2} \mathrm{O}\end{array}$ & $\begin{array}{l}\text { leaf water extracts + Hoagland } \\
2+\mathrm{MgSO}_{4} \cdot 7 \mathrm{H}_{2} \mathrm{O}\end{array}$ & $\mathrm{PP}+\mathrm{Mg}$ \\
\hline 4 & $\begin{array}{l}\mathrm{H}_{2} \mathrm{O}+\text { Hoagland } 2+2 \times \mathrm{MgSO}_{4} \\
\cdot 7 \mathrm{H}_{2} \mathrm{O}\end{array}$ & $\begin{array}{l}\text { leaf water extracts }+ \text { Hoagland } 2 \\
+2 \times \mathrm{MgSO}_{4} \cdot 7 \mathrm{H}_{2} \mathrm{O}\end{array}$ & $\mathrm{PP}+2 \mathrm{Mg}$ \\
\hline \multicolumn{4}{|c|}{$\begin{array}{l}\text { Hoagland } 2 \text { composition: } \mathrm{Ca}\left(\mathrm{NO}_{3}\right)_{2} \cdot 4 \mathrm{H}_{2} \mathrm{O}-0.95 \mathrm{~g} \cdot \mathrm{l}^{-1} ; \mathrm{KNO}_{3}-0.61 \mathrm{~g} \cdot \mathrm{l}^{-1} ; \mathrm{MgSO}_{4} \cdot 7 \mathrm{H}_{2} \mathrm{O}- \\
-0.49 \mathrm{~g} \cdot \mathrm{l}^{-1} ; \mathrm{NH}_{4} \mathrm{H}_{2} \mathrm{PO}_{4}-0.12 \mathrm{~g} \cdot \mathrm{l}^{-1} ; \mathrm{H}_{3} \mathrm{BO}_{3}-620 \mathrm{mg} ; \mathrm{MnCl}_{2} \cdot 4 \mathrm{H}_{2} \mathrm{O}-290 \mathrm{mg} ; \mathrm{CuSO}^{-} \cdot 5 \mathrm{H}_{2} \mathrm{O}- \\
-60 \mathrm{mg} ; \mathrm{ZnSO}_{4} \cdot 7 \mathrm{H}_{2} \mathrm{O}-60 \mathrm{mg} ;\left(\mathrm{NH}_{4}\right) 6 \mathrm{Mo}_{24}-50 \mathrm{mg} ; \mathrm{KJ}-30 \mathrm{mg} ; \mathrm{CoCl}_{2}-60 \mathrm{mg} \text {. } \\
\text { Explanations: } \mathrm{BP} \text { - without Hoagland } 2 \text { nutrient solution; } \mathrm{PP}-\text { with Hoagland } 2 \text { nutrient } \\
\text { solution; } \mathrm{PP}+\mathrm{Mg} \text { - with Hoagland } 2 \text { nutrient solution }+\mathrm{MgSO}_{4} \cdot 7 \mathrm{H}_{2} \mathrm{O}-0.49 \mathrm{~g} \cdot l^{-1} ; \mathrm{PP}+2 \mathrm{Mg}- \\
\text { with Hoagland } 2 \text { nutrient solution }+\mathrm{MgSO}_{4} \cdot 7 \mathrm{H}_{2} \mathrm{O}-0.98 \mathrm{~g} \cdot \mathrm{l}^{-1}\end{array}$} \\
\hline
\end{tabular}

To obtain the water extracts, leaves of Festuca arundinacea $(F a), L o-$ lium multiflorum (Lm), Lolium perenne ( $(\mathrm{p})$, Phleum pratense (Php) and Poa pratense $(\mathrm{Pp})$ were collected from the plants at the tillering stage. The plant material (50 $\mathrm{g}$ of dried leaves from each species) was submerged with $1000 \mathrm{ml}$ of distilled water for $24 \mathrm{~h}$ and the solution was percolated through filter paper. The extracts were stored at $5^{\circ} \mathrm{C}$.

Phleum pratense seeds (each sample of 20 seeds selected manually) were laid in Petri dishes onto 3-ply layer of chromatography paper (Whatman No 3001917). The paper was moistened every day with $3 \mathrm{ml}$ of suitable water extracts from the studied grass leaves (leaf extract, extract + nutrient solution; extract + nutrient solution $+\mathrm{MgSO}_{4} \cdot 7 \mathrm{H}_{2} \mathrm{O}$ and finally, extract + 
+ nutrient solution + double dose of $\mathrm{MgSO}_{4} \cdot 7 \mathrm{H}_{2} \mathrm{O}$ ). The control was made up by the objects in which the blotting paper was moistened only with distilled water, distilled water with nutrient solution, distilled water with nutrient solution enriched with $\mathrm{MgSO}_{4} \cdot 7 \mathrm{H}_{2} \mathrm{O}$ and finally distilled water with nutrient solution improved with double dose of $\mathrm{MgSO}_{4} \cdot 7 \mathrm{H}_{2} \mathrm{O}$.

Germination energy of Phleum pratense seeds was assessed after five days (DORYWALSKI 1964) and the results were given as a percentage of germinated seeds. On the same day, measurements of the root system length and seedlings height were performed. The experimental results were analysed statistically using standard ANOVA. To verify the significance of differences between the studied means the Tukey confidence intervals $(p \leq 0.05)$ were applied.

\section{RESULTS AND DISCUSSION}

The research results proved that the water extracts from leaves of all the grass species studied significantly inhibited the initial growth and development of Ph. pratense (Figure 1).
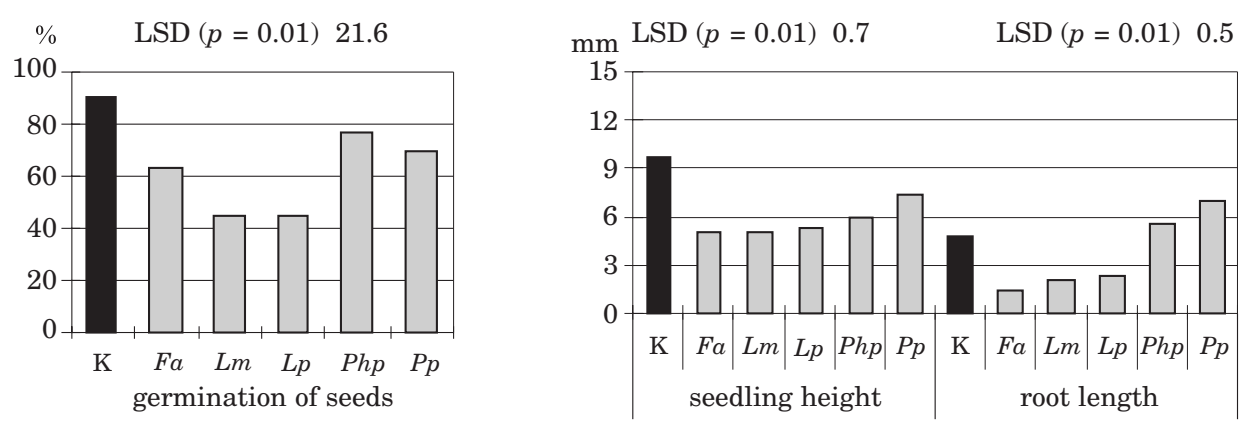

Fig. 1. Germination of seeds, seedling height and length of Ph. pratense roots under $F a, L m$, $L p, P h p$ and $P p$ leaf water extracts and control treatments (K)

Irrespective of the $\mathrm{BP}, \mathrm{PP}, \mathrm{PP}+\mathrm{Mg}$ and $\mathrm{PP}+2 \mathrm{Mg}$ objects used, the poorest germination of seeds of a tested species was reported in the objects with the water extracts from leaves of $L$. multiflorum and L. perenne. Substantial germination inhibition was also induced by the extracts from $F$. arundinacea, while the lowest from $P$. pratense and $P$. pratensis (Figure 2a). On the other hand, the addition of nutrient solution with or without magnesium sulfate significantly reduced the inhibitory effect of the extracts. The inhibitory influence of water extracts from $F a, L m, L p, P h p$ and $P p$ leaves was neutralized by Hoagland 2 (PP) nutrient solution alone. However, 
a magnesium supplement contributed extremely to the increase of germinated seed number of a tested species $(\mathrm{PP}+\mathrm{Mg}, \mathrm{Pp}+2 \mathrm{Mg})$ and limited most of all the allelopathic activity of $L$. perenne and L. multiflorum (Figure 2b).
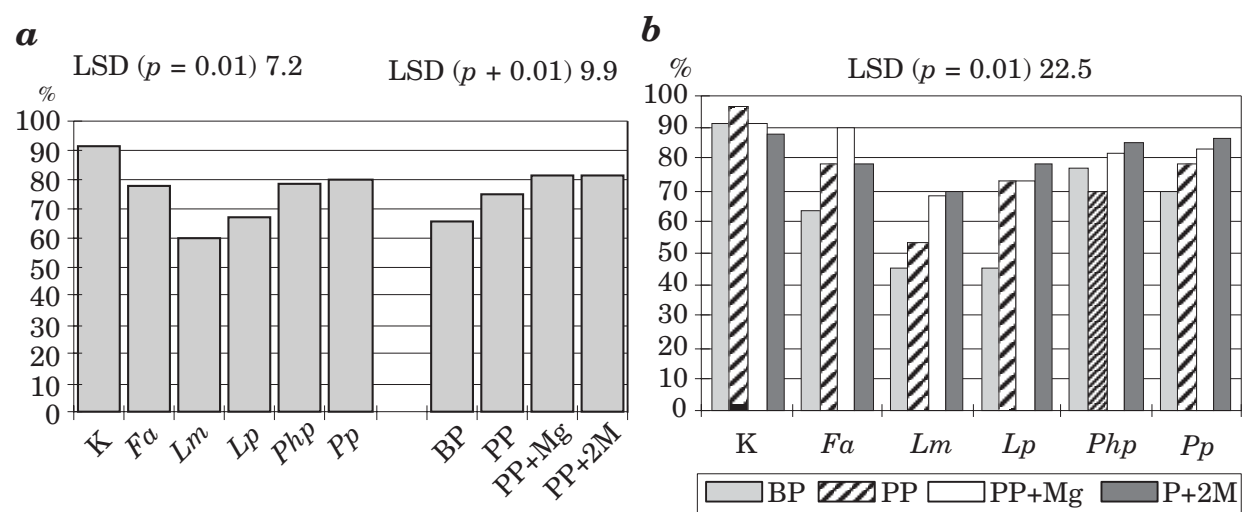

Fig. 2. Germination of $P h$. pratense seeds under $F a, L m, L p, P h p$, and $P p$ (BP) leaf water extracts treatments, leaf water extracts treatments, without any nutrient solution (PP), with addition of nutrient solution enriched with $\mathrm{Mg}$ or $2 \mathrm{Mg}$ and control treatments $(\mathrm{K})$

Among the species investigated in this research, growth of $P h$. pratense seedlings was mostly inhibited by $L$. perenne and $F$. arundinacea and to a lesser extend by $L$. multiflorum leaf extracts. The seedlings height, though, was limited to the smallest extent by the leaf water extracts of $P$. pratensis compared to the other species. These differences were statistically significant (Figure 3a).

Supplementation with either nutrient solution or magnesium sulfate to leaf water extracts (BP) promoted growth of Ph. pratense leaves. A single dose of magnesium sulfate proved most efficient in the objects with $\mathrm{L}$. multiflorum and Ph. pratense. However, Ph. pratense seedlings supplied with extracts made from $F$. arundinacea and $P$. pratensis leaves were taller when a double dose of magnesium sulfate was supplied compared to the objects supplied with the extracts alone (Figure $3 \mathrm{~b}$ ).

Irrespective of the applied neutralizers, the highest inhibition of $P h$. pratense roots development was imposed by leaf extracts of L. multiflorum, F. arundinacea and L. perenne. However, longer roots of the tested species were observed in the objects with water extracts from $P h$. pratense compared to the control (Figure 4a). Irrespective of species, a double dose of $\mathrm{MgSO}_{4} \cdot 7 \mathrm{H}_{2} \mathrm{O}(\mathrm{PP}+2 \mathrm{Mg})$ reduced the negative influence of the extracts from leaves (BP) most efficiently. A defensive mechanism of $\mathrm{MgSO}_{4} \cdot 7 \mathrm{H}_{2} \mathrm{O}$ at higher concentrations $(\mathrm{PP}+2 \mathrm{Mg})$ was apparent especially in the objects with extracts made from $L$. perenne and Ph. pratense leaves, whereas to a smaller extent from $F$. arundinacea $(4 \mathrm{~b})$. The employed doses of magnesium did not 

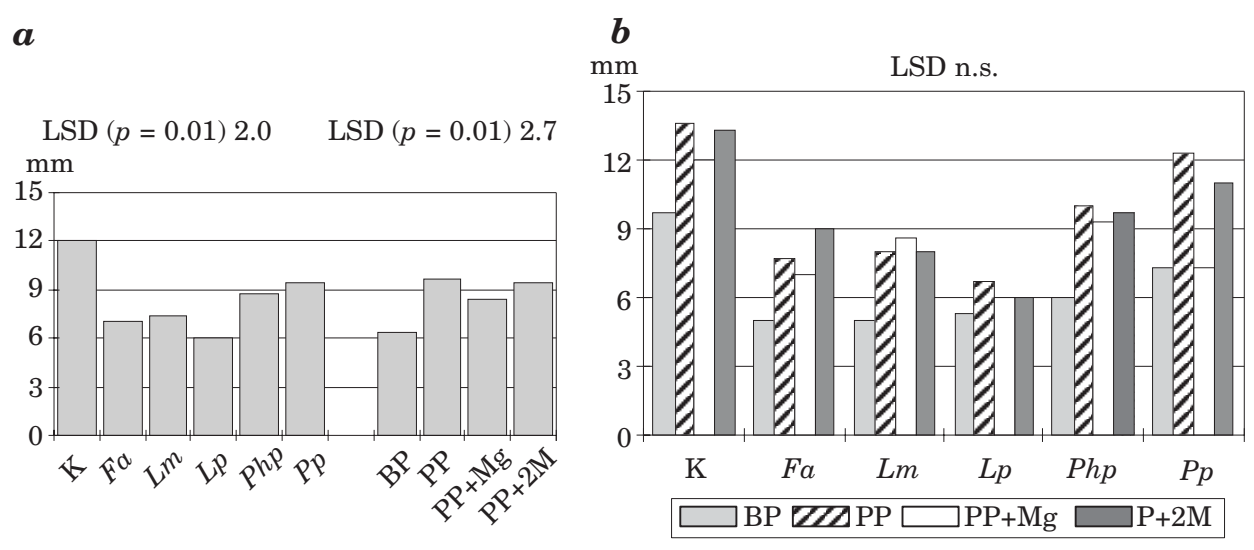

Fig. 3. Ph. pratense seedling height under $F a, L m, L p, P h p$, and $P p$ (BP) leaf water extracts treatments, leaf water extracts treatments, without any nutrient solution (PP), with addition of nutrient solution enriched with $\mathrm{Mg}$ or $2 \mathrm{Mg}$ and control treatments $(\mathrm{K})$

\section{a}

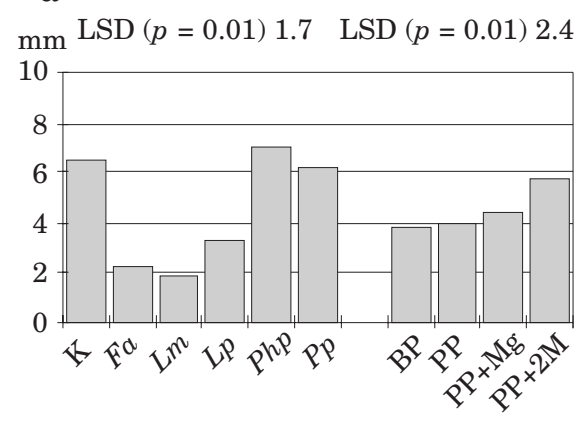

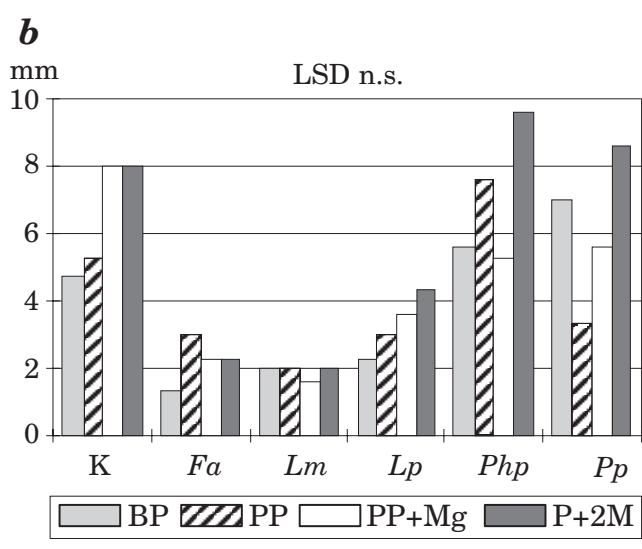

Fig. 4. Length of $P h$. pratense roots under $F a, L m, L p, P h p$, and $P p$ (BP) leaf water extracts treatments, without any nutrient solution (PP), with addition of nutrient solution enriched with $\mathrm{Mg}$ or $2 \mathrm{Mg}$ and control treatments $(\mathrm{K})$

ameliorate the negative impact of the extracts prepared from L. multiflorum leaves.

According to previous studies, supplementation with active carbon can reduce the negative effects of allelochemicals (CALLAWAY, AscheHoug 2000, MAHALL, CALLAWAY 1992). ZaCKRISSON et al. (1996) claim that charcoal produced during the fires of the boreal forests causes appreciable reduction of phenols activity. Charcoal can play a key role in the neutralization of some detrimental effects of Empetrum hermaphroditum on the neighbouring species 
through the absorption of the allelopathic substances secreted from the tissues of this species (NILSson et al. 2000).

It was found that deficit of minerals in a number of plant species induces the increased production of allelopathic compounds (INDERJIT, DuKE 2003, Camacho-Cristobal et al. 2002). Blum et al. (1993) report that the presence of nitrates or carbon compounds in a soil modifies the allelopathic effect of $p$-coumaric acid. It was stated that a high nitrogen content in a form of nitrates enhanced its activity, whereas glucose or methionine reduced it of Ipomea hederacea growth. The research results of BLum et al. (1985) revealed that regeneration of cucumber seedlings after inhibiting by ferulic acid proceeded more promptly in an environment abundant in mineral components as compared to mineral deficits.

Among numerous fertilizer components, magnesium is of primary importance (FILIPEK 1996). The presence of its ions contributes to the adaptation process of plants to the stress conditions caused, among others, by the allelopathic activity (PALTA 1990). The activity of allelopathic substances activity is reported to disturb the course of metabolism as well as the physiological processes occurring in plants (BAZIRAMAKENGa et al. 1995, PolityckA 1997, Galindo 1999). Growth inhibition of cucumber root cells (Cucumis sativus) in the presence of alleopathic compounds was attributed to the disturbances in lipid metabolism and reduction of protein synthesis (BURGos et al. 2004). Moreover, the allelocompounds can inactivate some of enzymes, producing e.g. insoluble complexes with enzymatic proteins (PADHY 2000). They inhibit the intake of micro- and macroelements through a change in the hydraulic conductance of cell membrane (INDERJIT, DuKE 2003). The allelocompounds can also diminish the activity of $\mathrm{H}^{+}$-ATP's plasmalemma in the roots (HeJu, Koster 2004). Magnesium, as a positive ion, regulates the cell pressure and charge balance in a plant cell. It also participates in the enzyme activation. The most important function, though, is the phosphorylation of energy carriers which, if impaired, may inhibit plant growth (Palta 1990).

\section{CONCLUSIONS}

1. Water extracts from the leaves of the tested grass species reduced germination of Phleum pratense and significantly modified its initial growth.

2. Application of $\mathrm{MgSO}_{4} \cdot 7 \mathrm{H}_{2} \mathrm{O}$ in the research had a beneficial effect on elimination of the inhibitory influence of extracts from leaves of the tested species of meadow grasses on germination of Phleum pratense seeds. The addition of magnesium sulfate positively influenced the root length and height of Phleum pratense seedlings. 
3. The obtained results indicate possible elimination of the inhibitory effects of extracts from leaves of some grass species by the use of $\mathrm{MgSO}_{4} \cdot 7 \mathrm{H}_{2} \mathrm{O}$ during the initial stage of Phleum pratense growth and development.

\section{REFERENCES}

Baziramakenga R., Lcroux G.D., Simard R.R. 1995. Effect of benzoic and cinnamic acids on membrane permeability of soybean roots. J. Chem. Ecol., 21: 1271-1285.

Bertin C., Paul R.N., Duke S.O., Weston L.A. 2003. Laboratory assessment of the allelopathic effects of fine leaf fescues. J. Chem. Ecol., 29: 1919-1937.

Blum U., Dalton B.R., Shann J.R. 1985. Effects of ferulic and p-coumaric acids in nutrient culture on cucumber leaf expansion as influenced by pH. J. Chem. Ecol., 11: 1567-1582.

Blum U., Gerig T.M., Worsham A.D., King L.D. 1993. Modification of the allelopatic effects of p-kumaricc acid on morning-glory seedlings biomass by glucose,methionine and nitrate. J. Chem. Ecol.,19: 2791-2811.

Burgos N.R., Talbert R.E., Kim K.S., KuK Y.I. 2004. Growth inhibition and root ultrastructure of cucumber seedlings exposed to allelochemicals from rye (Secale cereale). J. Chem. Ecol., 30: 671-689.

Callaway R.M., Aschehoug E.T. 2000. Invasive plants versus their new and old neighbors: A mechanism for exotic invasion. Science, 290: 521-523.

Camacho-cristóbal J.J., Annzellotti D., Gonzálezfontez A. 2002. Changes in phenolic metabolism of tabbaco plants during short term boron deficiency. Plant. Biol. Bioch., 40: 997-1002.

Chung I.M., Miller D.A. 1995. Allelopathic influence of nine grass extracts on germination and seedling growth of alfalfa. Agronomy Journal, 87: 767-772.

Emeterio L.S., Arroyo A., Canals R.M. 2003. Allelopathic potential of Lolium rigidum Gaud. on the early growth of three associated pasture species. Grass and Forage Science, 59: 107-112.

FiLIPEK T. 1996. Biopierwiastki w produkcji roślinnej. Pr. Nauk. IV Ogóln. Symp. Magnezologicznego PTMag Magnez w środowisku cztowieka, Lublin, 43-50,

Galindo J.C.G., Hernandez A., Dayan F.E., Tellez M.R., Macias F.A., Paul R.N., Duke S.O. 1999. Dehydrozaluzanin C, a natural sesquiterpenolide. causes rapid plasma membrane leakage. Phytochemistry, 52: 805-813.

HeJL A.M., Koster K.L. 2004. Juglone disrupts root plasma membrane H+-ATPase activity and impairs water uptake, root respiration, and growth in soybean (Glycine max) and corn (Zea mays). J. Chem. Ecol., 30: 453-472.

INDERJIT, Duke, S.O. 2003. Ecophysiological aspects of allelopathy. Planta, 217: 529-539.

Leigh J.H., Halsall D.M., Holgate M. D. 1995. The role of allelopathy in legume decline in pastures. I. Effects of pasture and crop residues on germination and survival of subterranean clover in the field and nursery. Austr. J. Agric. Res., 46: 179-188.

LipiśsKa H. 2005. Allelopathic effects of grasses and biodiversity of plant communities. Grassland Science in Europe (eds. R. Lillak, R. VirRalt, A. Linke, V. Geherman), 10: 380-383.

Lipińska H., НАRкот W. 2005. Allelopathic effects of water leachates of Poa pratensis leaves. Allelopathy Journal, $16: 251-260$.

Mahall B.E., Callaway R.M. 1992. Root communication mechanisms and intracommunity distributions of two Mojave desert shrubs. Ecology, 73: 2145-2151. 
Nilsson M.C., Zackrisson O., Sterner O., Wallstedt A. 2000. Characterization of the differential interference effects of two boreal dwarf shrub species. Oecologia, 123: 122-128.

Padhy B., Patnaik P.K., Tripathy A.K. 2000. Allelopathic potential of Eucalyptus leaf litter leachates on germination and seedling growth of fingermillet. Allelopathy Journal, 7: 69-78.

Palta J.P. 1990. Stress interactions at the cellular and membrane levels. Hort Sci., 25: $1377-1381$.

PоLiтүска B. 1997. Free and glucosylated phenolics, phenol $\beta$-gIucosyltransferase aclivity and membrane permeability in cucumber roots affected by derivatives of cinnamic and benzoic acids. Acta Physiol. Plant., 19: 311-317.

Rice E.L. 1984. Allelopathy. Academic Press, New York

Ridenour W.M., Callaway R.M. 2001. The relative importance of allelopathy in interference: The effects of an invasive weed on a native bunchgrass. Oecologia, 126: 444-450.

Sмith A.E., Martin L.D. 1994. Allelopathic characteristics of three cool-season grass species in the forage ecosystem. Agronomy Journal, 86: 243-246.

Sutherland B.l., Hume D.E., TAPper B.A. 1999. Allelopathic effects of endophyte-infected perennial ryegrass extracts on white clover seedlings. New Zealand J. Agric. Res., 42: 19-26.

Zackrisson O., Nilsson M.c, Wardle D.A. 1996. Key ecological function from wildfire in Boreal forest. Oikos, 77: 10-19. 